\title{
Safety aspects for the R290 (propane) as working medium in small air conditioning installations
}

\author{
Andrzej GRZEBIELEC ${ }^{* 1}$, Artur RUSOWICZ ${ }^{1}$, and Adam SZELĄGOWSKI ${ }^{1}$ \\ ${ }^{1}$ Faculty of Power and Aeronautical Engineering, Warsaw University of Technology, Warsaw, Poland
}

\begin{abstract}
Following the entry into force of the Regulation (EU) No 517/2014 of the European Parliament and of the Council of 16 April 2014 on fluorinated greenhouse gases and repealing Regulation (EC) No 842/2006, the scope of refrigerants, which have so far been commonly used is very limited. All preferred refrigerants are mostly flammable and explosive, and they include R32, R1234yf, R1234ze, R290 (propane), R600a (isobutane), R717 (ammonia). However, it should be noted that refrigerants such as R32, R1234yf, R1234ze are classified as mildly flammable and has been created for them, in accordance with ISO 817 standard, special group called A2L. It is also worth noting that the new classification moved ammonia to the group B2L - that means is toxic and mildly flammable. The article focuses on defining the conditions in which there is possible to build safely split installation in which the propane is a refrigerant. It turns out that small splits are devices which can be used safely with R290 in most cases.
\end{abstract}

Keywords: refrigeration, refrigerant, propane, R290.

\section{Introduction}

In 2014, a new regulation of the European Parliament and of the Council came into force on refrigerants from the group called f-gases - certain fluorinated greenhouse gases [18]. The use of currently available refrigerants has once again been reduced [19]. This regulation is related to the direction of the development of the European Union's climate actions, which aims to continuously reduce emissions of $\mathrm{CO} 2$ and other greenhouse gases. [1]. The Global Warming Potential (GWP) coefficient was adopted as the parameter determining the greenhouse effect potential). Table 1 lists the GWP coefficients for current and prospective refrigerants.

Table 1 clearly shows that the refrigerants used today have a high level of GWP. This leads to a situation where, in the coming years, further refrigerants commonly used in air conditioning systems, heat pumps and refrigeration equipment will be phased out. The European Commission is moving towards the use of natural refrigerants [11]. In the coming years, only refrigerants such as: ammonia, carbon dioxide, propane, isobutane will be approved for use, from the group of hydrofluoroolefins there will be allowed only R1234ze, R1234yf [20]. All these natural refrigerants have been known in refrigeration for over 100 years, however, due to their flammability and explosiveness, they have lost the competition to synthetic agents such as R12 or R22, which are neither flammable nor toxic $[3,4]$ and do not cause corrosion of the installation [25]. R32, R1234ze, R1234yf refrigerants are included in the newly created A2L group, non-toxic and moderately flammable substances [21, 24, 27]. Fig. 1 shows the minimum ignition energy and the lower explosion limit in air for prospective refrigerants.

Figure 1 shows that the refrigerants from the A2L group pose a risk of explosion when their concentration is several times higher than in the case of propane, methane or isobutane, and in most cases they also require much more energy to ignite. It should also be added that the R1234ze refrigerant is non-flammable at temperatures below $30{ }^{\circ} \mathrm{C}$ [14]. Other parameters important from the point of view of the explosion hazard are the burn rate and the heat of combustion - these are defined as the potential damage that can be caused by gas ignition after leakage from the installation. These values for refrigerants are presented in Fig. 2. In this case also the factors from the A2L group

\footnotetext{
${ }^{*}$ Corresponding author: E-mail address: (andrzej.grzebielec@pw.edu.pl) Andrzej GRZEBIELEC
} 
Table 1. GWP coefficient for selected refrigerants

\begin{tabular}{|c|c|}
\hline Refrigerant & GWP \\
\hline R1234ze & 7 \\
\hline R1234yf & 4 \\
\hline R134a & 1430 \\
\hline R22 & 1810 \\
\hline R290 (propane) & 3 \\
\hline R32 & 675 \\
\hline R404A & 3922 \\
\hline R407C & 1770 \\
\hline R410A & 2018 \\
\hline R600a (isobutane) & 3.3 \\
\hline R717 (ammonia) & 0 \\
\hline R744 (carbon dioxide) & 1 \\
\hline
\end{tabular}

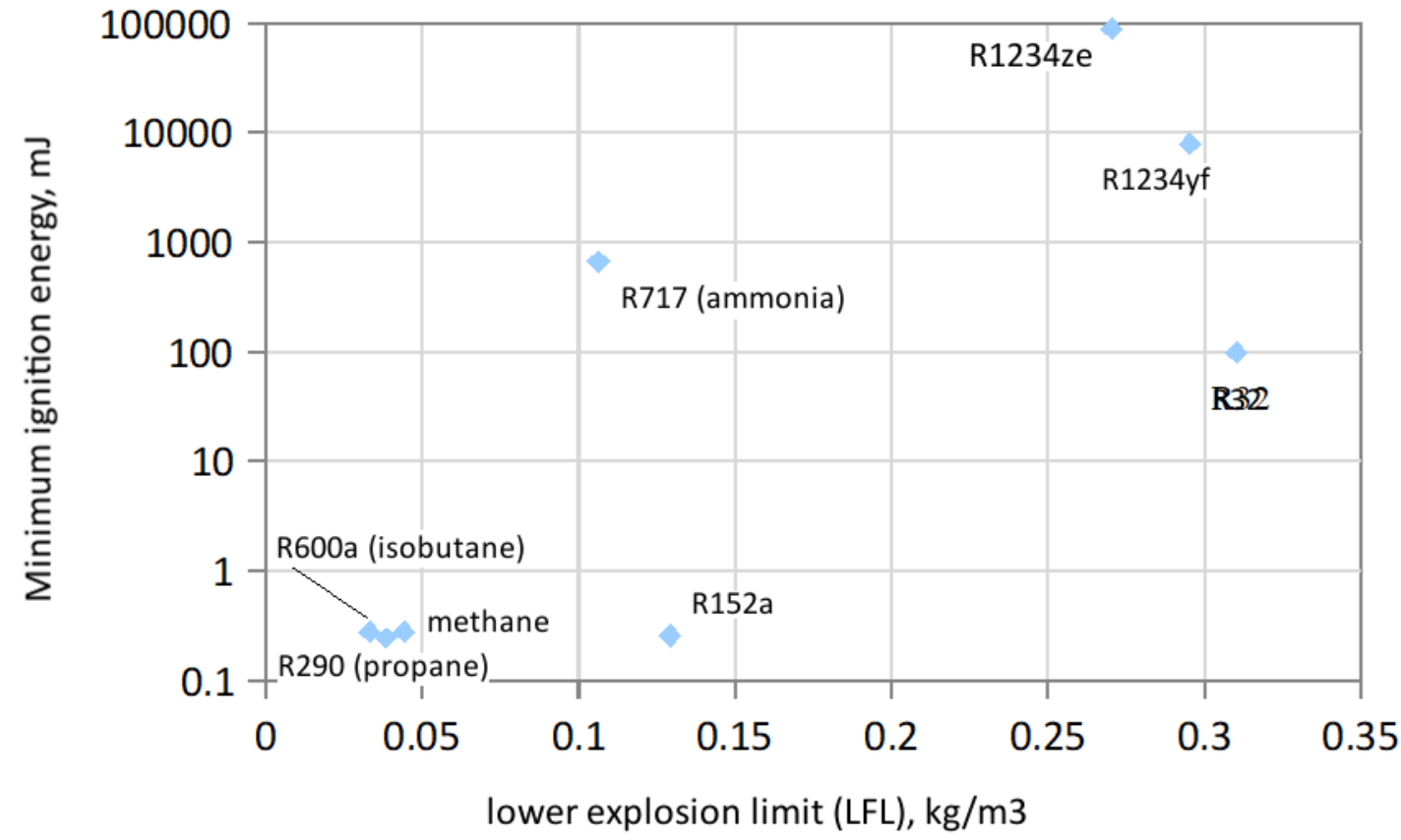

Figure 1. Minimum ignition energy as a function of the lower explosion limit (LFL) for flammable refrigerants.

fare much better. Potential leakage and ignition will not cause as much damage as leakage and ignition of propane or isobutane

The only refrigerant that is safe in terms of explosion hazard is R744 - carbon dioxide CO2, but it has other limitations:

- low temperature of the critical point $\left(30.4^{\circ} \mathrm{C}\right)$ - significantly reduces the use of carbon dioxide in typical cooling and air-conditioning installations;

- high operating pressures (condenser work over 100 bar);

Refrigerants from the hydrocarbon group (HC) are not a solution that is not available in refrigeration industry 


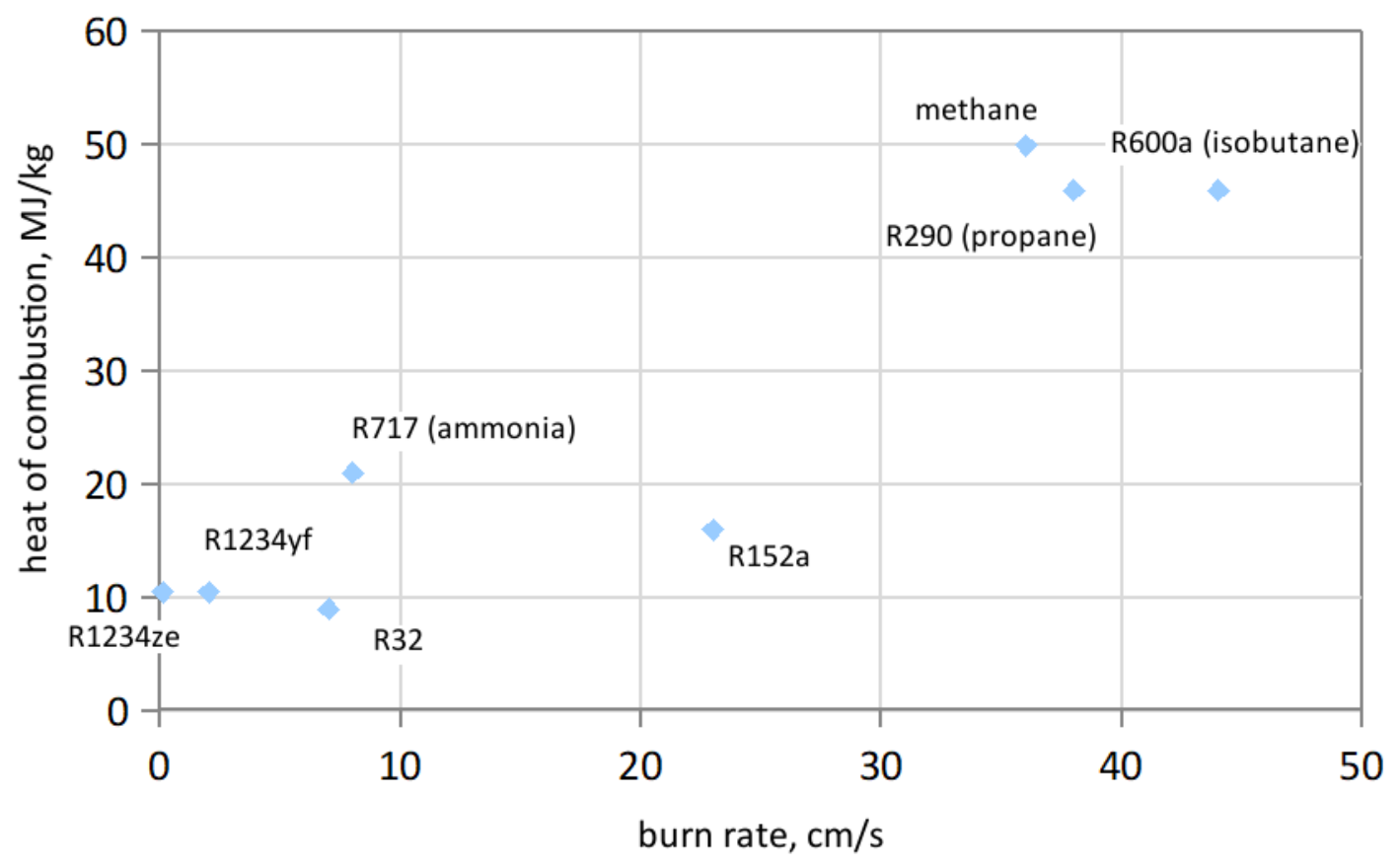

Figure 2. Combustion heat as a function of the combustion speed of refrigerants.

today. Isobutane has been the main refrigerant used in fridges in the European Union since the 1990s (over $90 \%$ of the market) $[11,12]$. Propane is often found in large industrial installations. On the other hand, ammonia can often be found in large installations of the food industry.

The new regulations favor the development of other technologies related to the reduction of energy consumption[2, $10,13,16,17]$, less dust emissions [15, 26], or the construction of non-compressor refrigeration equipment. In recent years, many absorption and adsorption cooling installations have been built [7] or with the use of the ejectors [23].

\section{Legal acts and standards regulating the use of propane in split air- conditioning systems}

Nine documents (legal acts and standards) are listed that should be taken into account in the aspect of construction and operation of devices and installations containing propane $[5,8]$. These documents are listed in table 2. After careful analysis of the documents, it turns out that in most cases, due to the small amount of the refrigerant, which is propane, in split units, the documents do not apply to them. The EN 378 standard turns out to be the most important.

The EN 378 standard says that devices with a filling capacity of less than 150 grams can be used anywhere. However, in larger installations, the standard defines the concept of the maximum charge with the working medium, which is calculated in accordance with the formula:

$$
M=2.5 \cdot L F L^{1.25} \cdot h \cdot A^{0.5}
$$

where:

$M$ - maximum filling of the installation with the refrigerant, $\mathrm{kg}$;

$L F L$ - lower explosive limit, $\mathrm{kg} / \mathrm{m}^{3}$; for propane LFL is equal to $0.038 \mathrm{~kg} / \mathrm{m}^{3}$.

$h$ - unit installation height, $\mathrm{m}$ (0.6 - floor unit, 1.0 - window unit; 1.8 - wall unit; 2.2 - ceiling unit);

$A$ - floor area, $\mathrm{m}^{2}$; 
Table 2. Legal acts and standards concerning flammable materials as refrigerants

\begin{tabular}{|c|c|}
\hline Act & Description \\
\hline ISO $817: 2014$ & Refrigerants - Designation and safety classification \\
\hline EN 378 & $\begin{array}{l}\text { Refrigerating systems and heat pumps } \\
\text { - Safety and environmental requirements }\end{array}$ \\
\hline EN 60079 & Explosive atmospheres \\
\hline EN 60335 & $\begin{array}{l}\text { Safety of household and similar } \\
\text { electrical appliances }\end{array}$ \\
\hline ADR & $\begin{array}{l}\text { European Agreement concerning } \\
\text { the International Carriage of Dangerous Goods by Road }\end{array}$ \\
\hline Dz.U. 2003 nr 86 poz. 789 & $\begin{array}{l}\text { Act of March } 28 \\
2003 \text { on rail transport }\end{array}$ \\
\hline Dz.U. 2010 nr 138 poz. 931. & $\begin{array}{l}\text { Regulation of the Minister of } \\
\text { Economy of } 8 \text { July } 2010 \text { on the minimum requirements for } \\
\text { occupational health and safety related to the } \\
\text { possibility of an explosive atmosphere in the workplace. }\end{array}$ \\
\hline Dz.U. 2015 poz. 881 & $\begin{array}{c}\text { Act of } 15 \text { May } 2015 \text { on substances that deplete the ozone layer } \\
\text { and some fluorinated greenhouse gases }\end{array}$ \\
\hline Regulation (EU) No 517/2014 & $\begin{array}{c}\text { Regulation (EU) No } 517 / 2014 \text { of the European Parliament } \\
\text { and of the Council of } 16 \text { April } 2014 \\
\text { on fluorinated greenhouse gases } \\
\text { and repealing Regulation (EC) No } 842 / 2006\end{array}$ \\
\hline
\end{tabular}

These restrictions apply only to devices located in the zone of continuous human habitation. For industrial installations - other regulations listed in Table 2 also apply.

\section{Propane in air-conditioning installations}

There are three types of air conditioning systems:

- split systems - one evaporator is located inside the room, one condenser with a compressor is located outside the building.

- multisplit systems, VRV , VRF - outside the building there is a central unit with a condenser / condensers and a compressor / compressors, the refrigerant is supplied to the building and then distributed to individual evaporators; 
- brine systems - secondary fluid systems - the so-called ice water generator (chiller) is located outside the building - while only chilled water (or brine) is supplied to fan coils inside the rooms.

In the case of VRV systems, the amount of refrigerant is so large that it is not practicable to maintain safety in air-conditioned rooms - hence, in these solutions it is not possible to use hydrocarbons as refrigerants. In the case of systems with chilled water generators, despite the fact that the actual cooling system has no connection with the air-conditioned space, the standard EN 378 [9], in the case of air conditioning for people's comfort, it requires the same limits as in the case of so-called direct evaporation installations. Installations with chilled water generators are usually large systems - this means that in these installations it is also impossible to use hydrocarbon refrigerants in accordance with applicable regulations.

For this reason, the split system used for air conditioning the room will be analyzed in the further part of the work. A device of this type is presented in Figure 3. A typical split device for cooling apartments or office spaces will be used for the analysis. The analysis will cover the replacement of the working medium with propane [22]. A typical $2.7 \mathrm{~kW}$ split uses approximately 700 grams of R410A refrigerant. The cooling capacity of $2.7 \mathrm{~kW}$ is sufficient to air-condition rooms with an area of about $20 \mathrm{~m} 2$ when the windows are facing south or west, and when the windows are facing east or north - the area of the rooms can reach up to $40 \mathrm{~m}^{2}$. Calculations will be made for rooms with a smaller area - i.e. $20 \mathrm{~m}^{2}$. Split devices are most often installed in the wall or ceiling mode - this is due to the favorable air circulation. Thus, assuming a wall positioning, a maximum level filling is achieved:

$$
M=2.5 \cdot 0.038^{1.25} \cdot 1.8 \cdot 20^{0.5}=0.338 \mathrm{~kg}
$$

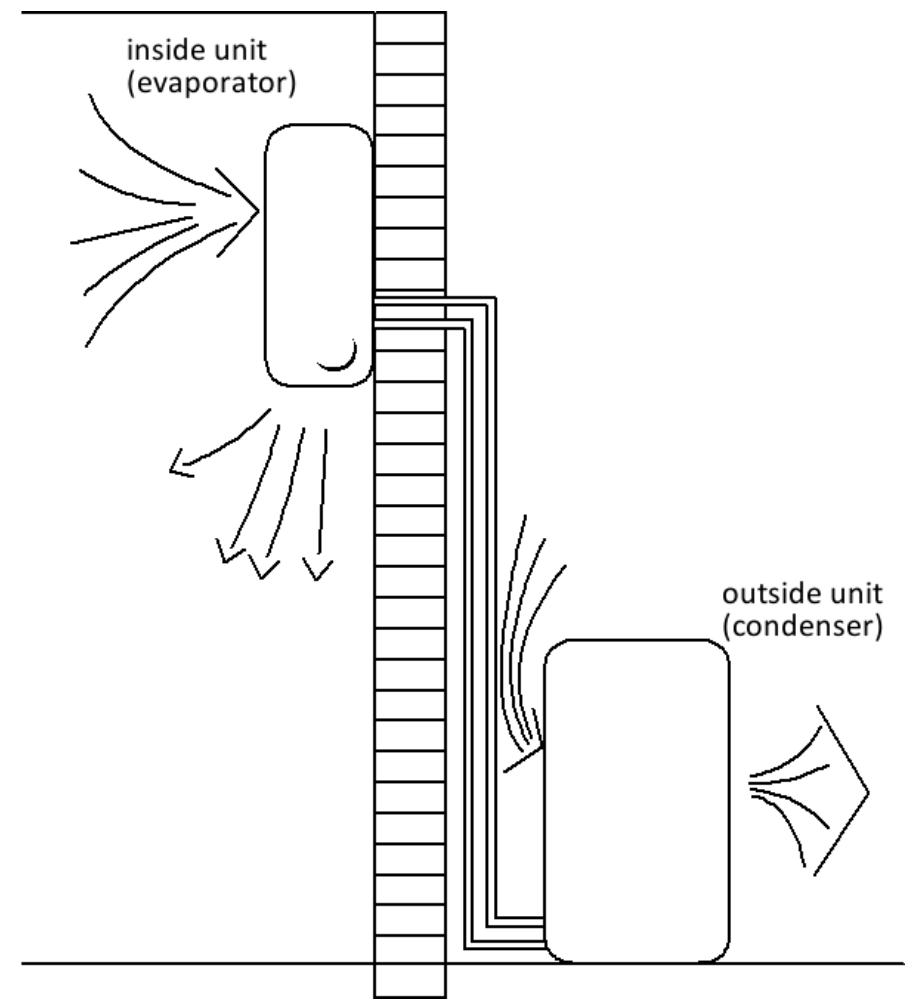

Figure 3. Split air conditioning unit with wall-mounted indoor unit.

In order to compare the difference between the charging of the same system with R410A refrigerant and R290, ln p-h graphs were prepared for both refrigerants (Fig. 4 and 5). At characteristic points, propane, compared to R410A, has an average density of 2.59 times lower, which means that it can be estimated that in a device with 700 grams of R410A there will be just 271 grams of propane. The presented estimate is indicative, because for each system this number should be determined experimentally, as it depends on the size of the heat exchangers, the size of the compressor and the length of the pipelines between the evaporator and the outdoor unit.

Experimental studies for refrigerants such as R22, R404A, R407C show that the amount of propane compared to the original refrigerant is reduced by 4 to 5 times [6]. This suggests that in a system where R410A was replaced 


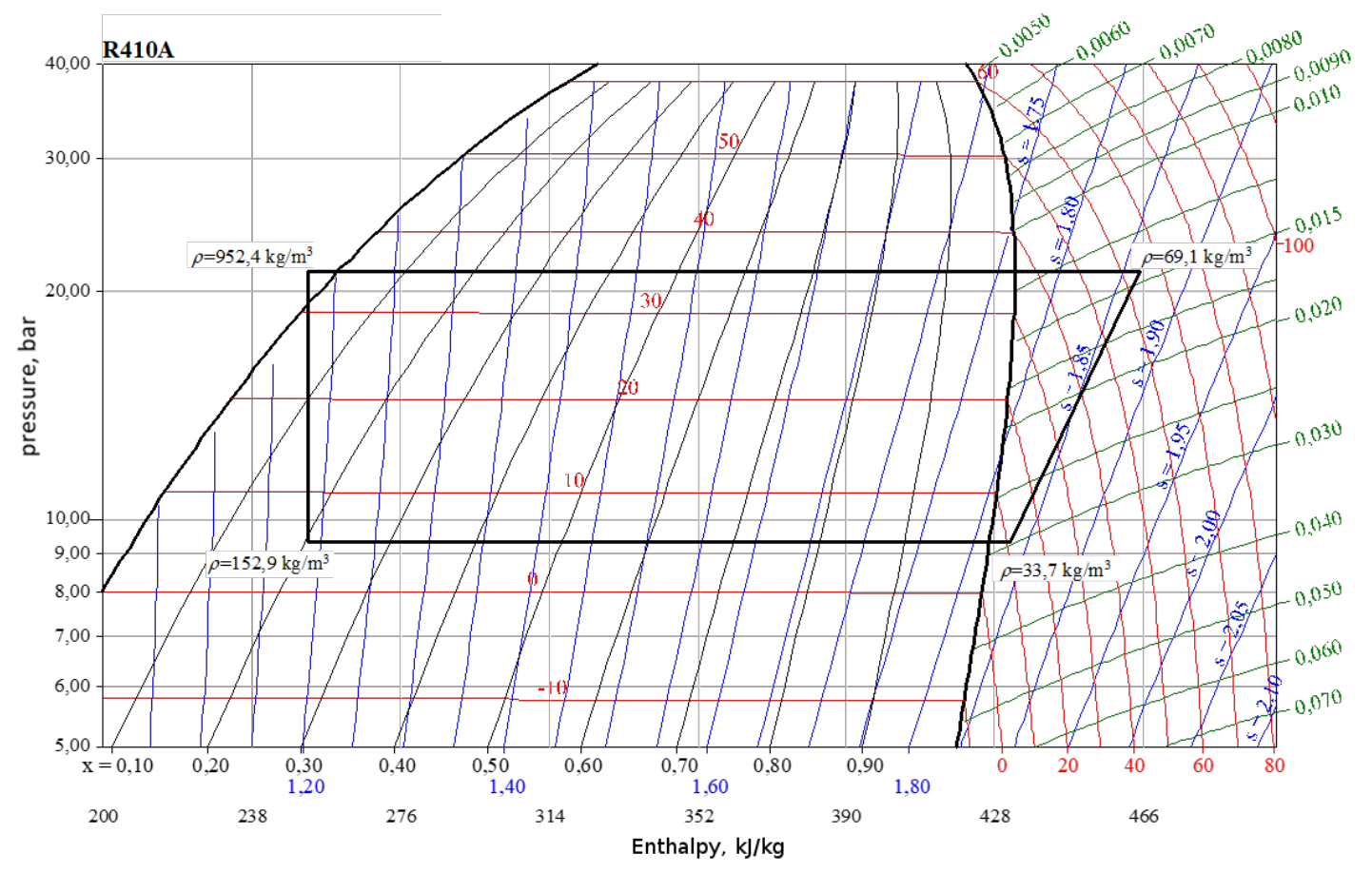

Figure 4. The lnp-h cycle of R410A refrigerant for the considered case

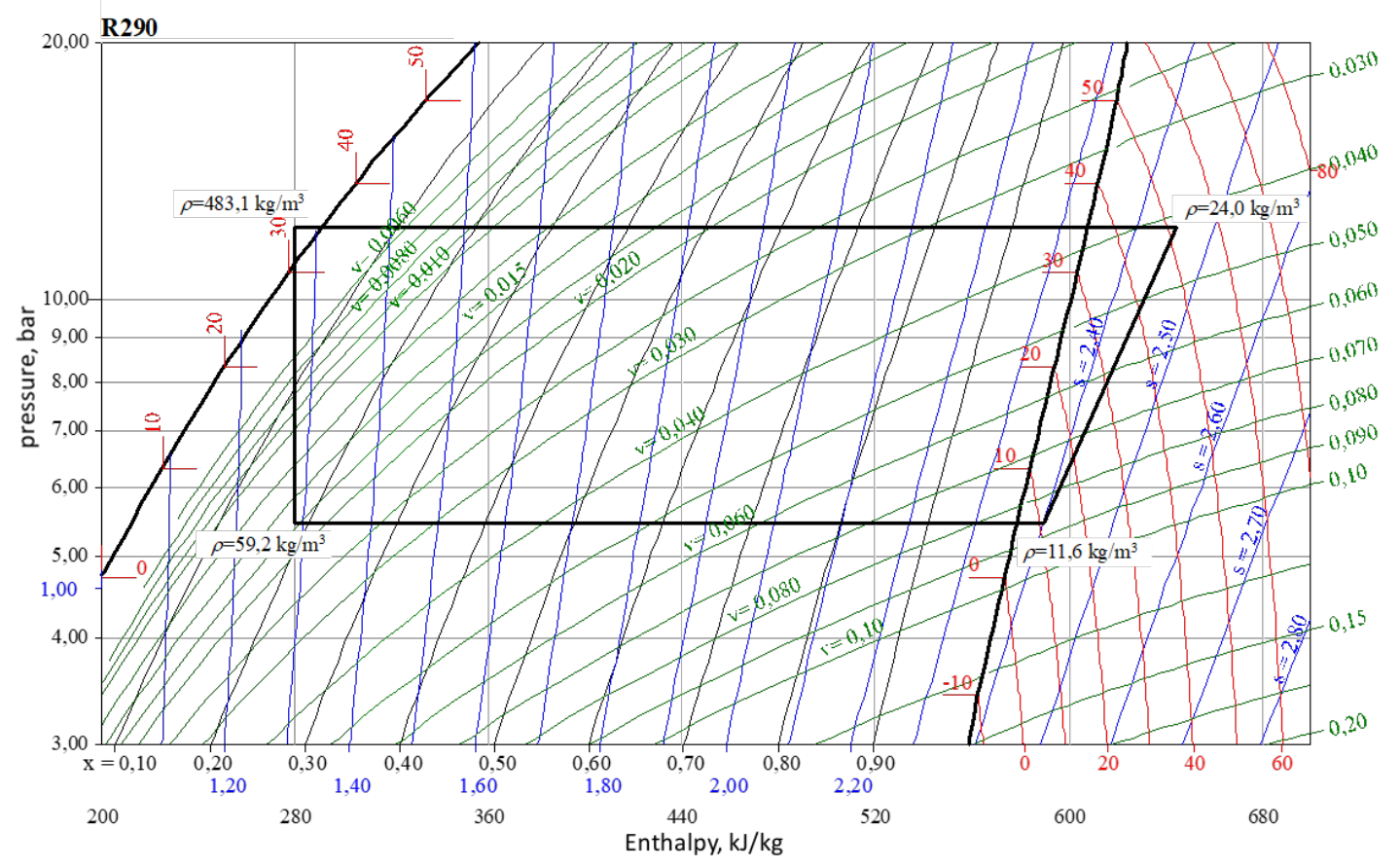

Figure 5. The lnp-h cycle for R290 (propane) for the considered case

with propane, its amount will be even less than the estimated 271 grams. The R410A refrigerant unit with a cooling capacity of $2.7 \mathrm{~kW}$ has a compressor volumetric capacity of $1.6066 \mathrm{~m}^{3} / \mathrm{h}$. If it is planned to replace the refrigerant in an operating system with R290, the volumetric capacity of the compressor will remain the same - it results from the design of the compressor. However, for the same volumetric capacity of the compressor, only $1.601 \mathrm{~kW}$ of cooling power can be obtained in the system with R290. For a propane system, replace the compressor with one with a higher volumetric capacity to obtain the same cooling capacity. The sizes of the heat exchangers can remain unchanged. This is because propane's thermal conductivity is greater than that of R410A. This fact means that the amount of 
refrigerant after replacing the compressor may also remain unchanged at 271 grams.

\section{Conclusions}

The conducted analysis shows that in small split air-conditioning systems, it is safe to use a refrigerant such as propane, because even the leakage of the entire amount of gas does not pose an explosion hazard. However, there is always a risk that the gas will ignite locally during service or disposal, so these activities should be performed only by qualified personnel. The amount of refrigerant in the installation, compared to the refrigerants currently used, is reduced by 2 to 5 times. In the case of the analyzed installation, 700 grams of R410A can successfully replace 271 grams of propane. However, a simple exchange of the refrigerant with one to another in an operating installation causes a reduction of the cooling capacity by $41 \%$. Due to this phenomenon, the cooling capacity may not be sufficient to maintain thermal comfort in the room. Due to the high thermal conductivity of propane, the heat exchangers are of sufficient size. Only the compressor per unit with higher volumetric capacity needs to be replaced. Another important consideration when replacing the refrigerant with propane is that propane has a density lower than that of oil. As a result, the oil transport will be different than in standard systems with synthetic agents. In large installations it would require reconstruction of pipelines and exchangers, in the case of split devices there is no such need.

\section{References}

1. Bartela, L., Skorek-Osikowska, A. \& Kotowicz, J. An analysis of the investment risk related to the integration of a supercritical coal-fired combined heat and power plant with an absorption installation for $\mathrm{CO} 2$ separation. Applied Energy 156, 423-435 (2015).

2. Baryłka, A. The impact of fire on changing the strngth of the underground shelter structure. Rynek Energii 146, 71-75 (1 2020).

3. Bohdal, T., Charun, H. \& Sikora, M. Empirical study of heterogeneous refrigerant condensation in pipe minichannels. International Journal of Refrigeration 59, 210-223 (2015).

4. Bohdal, T., Widomska, K. \& Sikora, M. The analysis of thermal and flow characteristics of the condensation of refrigerant zeotropic mixtures in minichannels. Archives of Thermodynamics 37, 41-69 (2 2016).

5. BRA: Guide to Flammable Refrigerants (2012).

6. Colbourne, D. \& Huhren, R. Operation of split air conditioning systems with hydrocarbon refrigerant. A conversion guide for technicians, trainers and engineers. Deutsche Gesellschaft für Internationale Zusammenarbeit (GIZ) GmbH - German International Cooperation -Programme Proklima (Eschborn, Germany, 2011).

7. Cyklis, P. Two stage ecological hybrid sorption-compression refrigeration cycle. International Journal of Refrigeration 48, 121-131 (2014).

8. Dz.U. 2010 nr 138 poz. 931. Rozporzadzenie Ministra Gospodarki z dnia 8 lipca 2010 r. w sprawie minimalnych wymagań, dotyczacych bezpieczeństwa $i$ higieny pracy, zwiazanych $z$ możliwościa wystapienia $w$ miejscu pracy atmosfery wybuchowej

9. EN 378: Refrigerating systems and heat pumps - Safety and environmental requirements

10. Gourbi, A., Bousmaha, I., Brahami, M. \& Tilmatine, A. Numerical Study of a Hybrid Photovoltaic Power Supply System. Journal of Power Technologies 96, 137-144 (2 2016).

11. Grzebielec, A. Europa zmierza w kierunku naturalnych czynników chłodniczych. Chłodnictwo 9, 42-46 (2010).

12. Grzebielec, A. \& Rusowicz, A. Kierunki rozwoju syntetycznych czynników chłodniczych w Europie. Polska Energetyka Stoneczna 1-4, 45-49 (2012).

13. Harmanti, N., Folić, R., Magyar, Z., Drazić, J. \& Kurtowić-Folić, N. Building envelope influence on the annual energy performance in office buildings. Thermal Science 20, 679-693 (2 2016).

14. Honeywell. Solstice ze refrigerant (HFO-1234ze). The Environmental Alternative to traditional refrigerants (2014).

15. Kukfisz, B., Półka, M. \& Salamonowicz Z.and Woliński, M. Badania inertyzacji mieszanin pyłowo powietrznych. Przemyst Chemiczny 93, 103-106 (1 2014).

16. Laskowski, R. Relations for steam power plant condenser performance in off-design conditions in the function of inlet parameters and those relevant in reference conditions. Applied Thermal Engineering 103, 528-536 (2016).

17. Owczarek, M., Owczarek, S., Baryłka, A. \& Grzebielec, A. Measurement Method of Thermal Diffusivity of the Building Wall for Summer and Winter Seasons in Poland. Energies 14. ISSN: 1996-1073 (2021).

18. Rozporzadzenie Parlamentu Europejskiego i Rady (UE) nr 517/2014 z dnia 16 kwietnia 2014 r. w sprawie fluorowanych gazów cieplarnianych i uchylenia rozporzadzenia (WE) nr 842/2006 
19. Rucinski, A., Rusowicz, A., Grzebielec, A. \& Jaworski, M. Wycofywanie czynników chłodniczych i ich bezpieczna utylizacja. Logistyka 1, 116-22 (2016).

20. Ruciński, A., Rusowicz, A. \& Grzebielec, A. Czynniki chłodnicze w transporcie samochodowym - aspekty prawne i techniczne. Logistyka 5, 1303-1309 (2014).

21. Rusowicz, A., Grzbielec, A. \& Ruciński, A. Ocena zagrożeń związanych z wykorzystywaniem naturalnych czynników chłodniczych. Logistyka 5, 1310-1316 (2014).

22. Rusowicz, A. \& Grzebielec, A. Aspekty prawne i techniczne zmiany czynników chłodniczych w instalacjach chłodniczych i klimatyzacyjnych. Czasopismo Inżynierii Ladowej, Środowiska i Architektury, JCEEA 32, 359367 (62 2015).

23. Smierciew, K., Butrymowicz, D., Kwidzyński, R. \& Przybyliński, T. Analysis of application of two-phase injector in ejector refrigeration systems for isobutane. Applied Thermal Engineering 78, 630-639 (2015).

24. Spatz, M. \& Minor, B. HFO-1234yf A Low GWP Refrigerant For MAC in. Honeywell / DuPont Joint Collaboration. SAE World Congress - Detroit, Michigan, April 14-17 (2008).

25. Szczucka-Lasota, B. Opracowanie stanowiska do przeprowadzenia testów korozyjnych. Aparatura Badawcza $i$ Dydaktyczna 19, 303-308 (2014).

26. Szwast, M. \& Szwast, Z. A Mathematical Model of Membrane Gas Separation with Energy Transfer by Molecules of Gas Flowing in a Channel to Molecules Penetrating this Channel from the Adjacent Channe. Chemical and Process Engineering 36, 151-169 (2 2015).

27. The Japan Society of Refrigerating and Air Conditioning Engineers: Risk Assessment of Mildly Flammable Refrigerants, April 2014. 